\title{
Assessment of rainwater harvesting for domestic water supply in palestinian rural areas
}

\author{
Nidal Mahmoud ${ }^{1}$, William Hogland ${ }^{2}$, Michael Sokolov ${ }^{3}$, Vasily Rud ${ }^{3,4,5}$, and Nikita Myazin ${ }^{5 *}$ \\ ${ }^{1}$ Institute of Environmental and Water Studies (IEWS), Birzeit University, PO Box 14, Birzeit, \\ The west Bank, Palestine \\ ${ }^{2}$ Dept. of Biology and Environmental Science, Linnaeus University, SE-391 82 Kalmar, Sweden \\ ${ }^{3}$ All-Russian Research Institute of Phytopathology, Moscow Region, 143050, Russian Federation \\ ${ }^{4}$ The Ioffe Physical-Technical Institute, St.Petersburg, 194021, Russian Federation \\ ${ }^{5}$ Peter the Great St.Petersburg Polytechnic University, St.Petersburg, 195251, Russian Federation
}

\begin{abstract}
Rainwater harvesting in Palestine is a principal water resource that had been adopted since ancient times. However, the system had not been subjected to a thorough assessment. This paper aims at assessing the feasibility of rainwater harvesting for domestic water supply in Palestinian rural areas with special emphasis on socio-cultural and financial aspects as well as harvested water quality. Different methods were used to collect necessary data from a case study village, including literature review, observations, questionnaires and water quality measurement of freshly fallen and harvested rainwater samples. Moreover, domestic water demand and water supply from such a system were compared, and economic feasibility of applying this system was checked. The results revealed that harvested rainwater is a viable resource that can contribute considerably to minimizing water shortage.
\end{abstract}

\section{Introduction}

The West Bank/Palestine lies on the Western edge of the Asian continent and the eastern extremity of the Mediterranean Sea, in the heart of the Middle East. The West Bank covers an area of $5,844.5 \mathrm{~km} 2$, and is characterized by a great variation in elevations ranging between 1020 meters above sea level and 375 meter below sea level [1]. The rainfall in Palestine usually starts in the middle of October and continues up to the end of April. The amount of rainfall in the mountain areas has an average of $600 \mathrm{~mm}$ per year, and goes down to $100 \mathrm{~mm}$ as a minimum value in the Jordan Valley and Dead Sea area [2].

Palestinians, due to water shortage, have a very low water consumption rate; on average 70 L/capita.day (L/c.d), and even some residents typically use less than $30 \mathrm{~L} / \mathrm{c} . \mathrm{d}$ [3]. Of the total West Bank population, 12.3\% has no access to piped water supply [3], and depends mainly on rainwater harvesting from rooftops and local springs. Even people who are connected to water supply networks suffer from occasional interruption in water supply, and frequently use harvested rainwater. Palestinians built rainwater harvesting systems from roof catchments already hundreds of years ago. The number of cisterns in the West Bank is 82656 cisterns. Of these, 5574 cisterns are located in Ramallah district where this study was

\footnotetext{
*Corresponding author: myazin.n@list.ru
} 
conducted, with 738 cisterns in localities without water supply distribution network, and 4836 cisterns in localities with distribution network [1].

Rainwater harvesting systems are independent from public centralized infrastructure, therefore very appropriate for isolated and disperse rural communities. Besides they are built of local materials and by local labours. Therefore, the developed methods of calculation and optimization of such facilities [4-7] are not applicable. In addition, there are some drawbacks and apparently rather miss perceptions and wrong practices regarding rainwater harvesting. Palestinians consider roof catchment's system as the most appropriate system in which rainwater can be used for domestic purposes "without" a need to treatment. Rainwater is collected by Palestinian households in cisterns with an average volume of $70 \mathrm{~m}^{3}$ each [1] regardless of the catchment's area, or number of persons and water demand, etc. The financial aspects of the harvested rainwater systems and the relation with the cost of getting water from other secondary water sources like purchasing water from water distribution tankers, who collect water from nearby available springs, have not been investigated. Harvested water might not be a dependable water source in times of dry weather or prolonged drought. Rain water collection from roof catchments have some drawbacks like (1) high initial capital cost, (2) limited quantity depending on the surface area and the duration of the drought period, and (3) undesirable taste due to limited mineral content. Another concern is that wastewater in the Palestinian villages is collected in cesspits which are potential non-point source of pollution threatening the quality of harvested rainwater [8].

This paper discusses the (1) technical elements (quantity of harvested water, water demand, available techniques), (2) economical dimensions (capital cost, economic added value, affordability), (3) social aspects (community need for harvested water, community perceptions, role of women, house on site and community facilities) and (4) hygienic aspects (microbial and physico-chemical characteristics), of rain water harvesting in the Palestinian rural areas which are essential for assessing the feasibility of the system. Almazra'a Al Gharbiyya village was chosen as a case study model of middle income localities living under water stressed environments.

\section{Materials and methods}

\subsection{Study area}

Almazra'a Al Gharbiyya village is situated on a mountainous area around $10 \mathrm{Km}$ North West of Ramallah City at an altitude of about $650 \mathrm{~m}$ above sea level. Approximately 5000 inhabitants live in the village distributed over 446 families. That entails a large family size which is a typical characteristic of developing countries [9]. The village is served with water supply network. About half of the families use rainwater-harvesting systems for domestic uses. Based on the construction method, two types of underground cisterns exist: pear shaped (excavated in rocks) and rectangular shaped (constructed from reinforced concrete). The village is not served with a sewerage network, and use cesspits.

\subsection{Field investigations}

Several site visits were conducted to Almazra'a Al Gharbiyya village during November to check the rainwater harvesting cisterns and used appliances, to fill in questionnaires, and to collect water samples for analysis. The analysis of samples was carried out by several methods, including the latest developments [11-13]. The obtained data was analysed qualitatively and quantitatively. 


\subsection{Questionnaire}

A questionnaire was designed and written in Arabic, viz. the respondent's mother language, and a one adult person from each household was interviewed. A random sample of 60 families was selected, divided in two categories, viz. 30 families with underground cistern and 30 families without underground cistern so their attitudes, water consumption, and perceptions about rainwater harvesting could be compared. The collected data were analysed using the SPSS software (Statistical Package for Social Science). The significance effect of the studied parameters on the water consumption was examined using ANNOVA test. The variables with significance level of 0.05 or less were considered significant.

The questionnaire focused on the following main issues:

- Family structure and level of education.

- Water consumption and resources.

- Existence and acceptability of rainwater harvesting systems.

- Uses of harvested water and sources of contamination.

\subsection{Analytical methods}

Harvested and freshly fallen rainwater samples were tested according to [14-17] for physical, chemical and microbiological parameters including temperature, $\mathrm{pH}$, salinity, conductivity, TDS, DO, turbidity, Faecal coliform (FC), $\mathrm{BOD}_{5}, \mathrm{PO}_{4}{ }^{3-}$, ammonia, and sulphate. The quality of the harvested rainwater was assessed for four randomly chosen cisterns twice over a one month period. Two fresh rainwater samples were collected before falling on the roof and analysed.

\subsection{Field investigations}

The records of water consumption from the water supply network of 50 families in Almazra'a Al Gharbiyya village were obtained from the water supply company, Jerusalem Water Undertaking (JWU). Since water supply by the network is intermittent during the summer period, the quantity of harvested rainwater needed to cover the water demand during water interruption was calculated.

\subsection{Financial feasibility}

The capital cost of both the pear and rectangular shaped underground cisterns were computed. The economic analysis is based on the equivalent worth method achieved by computing the present worth of all the annual disbursements for water consumption and the capital cost of constructing underground cisterns including excavation, material, labours and accessories. In order to assess the economic feasibility of the rainwater harvesting systems in Almazra'a village, water prices of three scenario cases were considered and compared; (1) families without cisterns, (2) families having rectangular shaped cistern and (3) families having pear shaped cistern. For each case the monthly water demand were obtained and the present worth of these expenses for a period of 50 years with an interest rate of $2 \%$ (average interest rate obtained from local banks) were calculated, then compared with the present worth of the capital investment cost of a cistern.

$$
\text { Present worth of the annual expenses }=\mathrm{A} \times \frac{(1+i)^{n}-1}{i(1+i)^{n}}
$$

Where: $A-$ the annual expenses for water consumption (US\$/year);

$i$ - interest rate that can be obtained from a bank $(\%)$;

$n$ - life time of an underground cistern (years). 


\section{Results and discussion}

\subsection{General overview of rainwater harvesting}

The field investigations revealed that rainwater harvesting have high social appropriation (convenient as they are easily available, etc.) and acceptability (used almost for all purposes). People consider rainwater harvesting cisterns as an essential component of their houses as being inherited through generations. They believe that rainwater harvesting is the best solution to alleviate water scarcity problems; at the same time they believe that they harvest water of good quality. Women have a considerable role in planning, design and construction of rainwater harvesting system. They are the ones who provide and manage the water use of the households.

The average size of cisterns found in the village is $55 \mathrm{~m}^{3}$ (range of $20-80 \mathrm{~m}^{3}$, STD 14.56) (Table 1). Almost $50 \%$ of the families have private cistern. Each cistern is usually used by more than one family; on average 2.64 families. Most of the cisterns are rectangular and constructed from reinforced concrete, but $20 \%$ are pear shaped excavated in rock. Gutters and down pipes used to convey the harvested rainwater to the cistern are mostly from metal and plastic. An inlet screen, a metal mesh with a maximum opening of $1 \mathrm{~mm}$, is provided to prevent entry of dry leaves and other debris into the down pipe [2]. The average age of the cisterns is 28.32 years (STD 8.34), and the newest cistern ages 15 years. This indicates that rainwater harvesting is an old practice which is apparently declining. In the past, cisterns were constructed and excavated manually, but nowadays people don't construct their own cistern manually and construction is limited due to financial constraints of constructing rectangular shaped cisterns as discussed later which apparently reflects people reluctance and shift in behaviour.

A foul flush system is used to divert the first flush from the cistern to avoid polluting the harvested rainwater, at the beginning of the rainy season. Roofs are only cleaned once a year before the first shower and the first flush is not conveyed. The harvested rainwater is withdrawn either by a pump or just by using a bucket tied to a robe. Operation and maintenance are very simple and consist particularly of cleaning the cistern at the beginning of the rainy period, and solids from the cistern influent by passing through a screen. So running costs for operation and maintenance can be neglected.

The results indicate with poor significance $(p<0.05)$ that water consumption from the water supply network of the families having underground cisterns are higher than those of the families without a cistern. The per capita water consumption is inversely proportional with the family size due to common housekeeping uses (person correlation is -0.462). The family size and the number of children are the most significant parameters affecting the water consumption $(p<0.05)$ (Table 1).

Table 1. Survey results for 30 families have rainwater harvesting system and 30 families haven't

\begin{tabular}{|c|c|c|c|c|c|}
\hline & \multirow{2}{*}{ Units } & \multicolumn{2}{|c|}{$\begin{array}{c}\text { For 30 families with } \\
\text { Underground cisterns }\end{array}$} & \multicolumn{2}{c|}{$\begin{array}{c}\text { For 30 families without } \\
\text { underground cisterns }\end{array}$} \\
\cline { 3 - 6 } & & Mean & Std. Deviation & Mean & Std. Deviation \\
\hline $\begin{array}{c}\text { Per capita water } \\
\text { consumption }\end{array}$ & L/c.d & 70.14 & 46.62 & 55.39 & 34.46 \\
\hline $\begin{array}{c}\text { family size } \\
\text { no. of children }\end{array}$ & $\#$ & 8.50 & 3.61 & 9.07 & 4.40 \\
\hline $\begin{array}{c}\text { no./week using the } \\
\text { washing machine }\end{array}$ & $\# /$ week & 3.25 & 1.82 & 2.71 & 1.15 \\
\hline
\end{tabular}




\section{EECE-2018}

\begin{tabular}{|c|c|c|c|c|c|}
\hline & \multirow[t]{2}{*}{ Units } & \multicolumn{2}{|c|}{$\begin{array}{l}\text { For } 30 \text { families with } \\
\text { Underground cisterns }\end{array}$} & \multicolumn{2}{|c|}{$\begin{array}{l}\text { For } 30 \text { families without } \\
\text { underground cisterns }\end{array}$} \\
\hline & & Mean & Std. Deviation & Mean & Std. Deviation \\
\hline $\begin{array}{l}\text { Days of water cut off } \\
\text { in summer per month }\end{array}$ & day & 15.54 & 5.30 & 13.89 & 7.89 \\
\hline $\begin{array}{l}\text { Size of underground } \\
\text { cistern }\end{array}$ & $\mathrm{m}^{3}$ & 55.00 & 15.03 & & \\
\hline $\begin{array}{c}\text { Age of underground } \\
\text { cistern }\end{array}$ & years & 28.32 & 8.41 & & \\
\hline $\begin{array}{c}\text { Number of families } \\
\text { using the underground } \\
\text { cistern }\end{array}$ & family & 2.64 & 1.81 & & \\
\hline $\begin{array}{c}\text { Distance from cesspit } \\
\text { to cistern }\end{array}$ & $\mathrm{m}$ & 16.68 & 32.06 & & \\
\hline Roof surface area & $\mathrm{m}^{2}$ & 132.14 & 68.60 & 134.64 & 52.95 \\
\hline $\begin{array}{c}\text { Number of roof top } \\
\text { plastic water storage } \\
\text { tank }\end{array}$ & \# & 1.07 & 1.02 & 0.79 & 1.01 \\
\hline $\begin{array}{c}\text { Number of roof top } \\
\text { metal water storage } \\
\text { tank }\end{array}$ & $\#$ & 1.04 & 0.92 & 1.10 & 0.77 \\
\hline
\end{tabular}

Of the total families, $30 \%$ have gardens, which are small lots of a few meter squares of land usually cultivated for household consumption with plants such as mints and parsley. Nevertheless, statistical analysis showed that having a garden significantly affects the water consumption $(p<0.05)$.

The available secondary sources used during water interruption in Almazra'a village are harvested water in cisterns, and purchased water from water distribution tankers. Fig. 1 shows that water from cisterns either borrowed from neighbours or from a private one is the most important secondary water source resembling $81 \%$ of the secondary sources. The second most common secondary source is purchased water from the water distribution tankers, which is rather expensive (3.33 US $\$$ per $\mathrm{m}^{3}$ ) but people are obliged to buy in the case of not having a cistern.

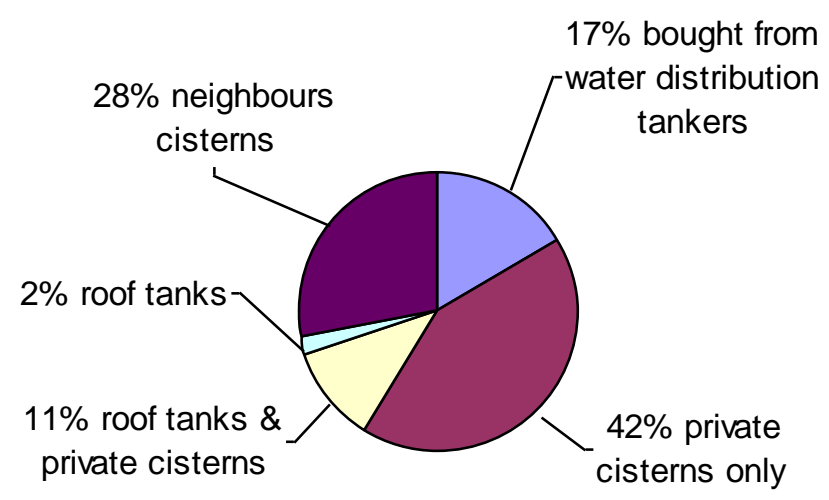

Fig. 1. Percentage of used water sources during water interruption in Almazra'a village

The education level in Almazra'a village is low as only $45 \%$ of the mothers finished primary school and $30 \%$ of them are illiterate. However, the results revealed that household 
status (income, education and occupation) have no significant impacts on water consumption rates.

\subsection{Uses of harvested rainwater}

The average days of water cut off during summer is around 15 days per month (Table 1). The families use the secondary water sources including harvested rainwater only during the days of water cut-off in summer. The results revealed that there are differences in the actual uses of harvested water by the families who have cisterns and the perceptions of the families who haven't (Fig. 2 and 3). While, $66 \%$ of the families who haven't a cistern accept to use the harvested water for all their needs including drinking, only about half of the families who have a cistern drink from the harvested rainwater, and so can depend completely on water from cisterns during water cut-off. This indicates that people without access to proper water resource, might use water of less quality. Apparently families without cisterns face more problems of the non-readily available secondary water resources during water interruption, so they are more willing to use the harvested water of "low" quality for drinking. Families who use harvested water for cooking believe that all the microbes would be eliminated by heat.

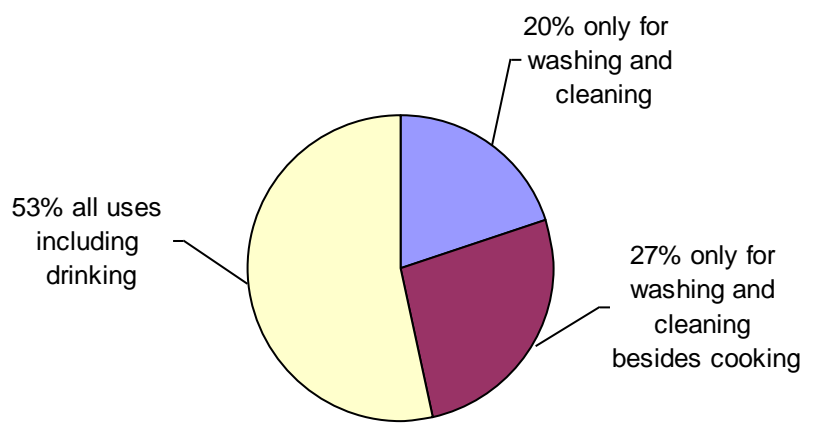

Fig. 2. Uses of harvested water for 30 families having cisterns

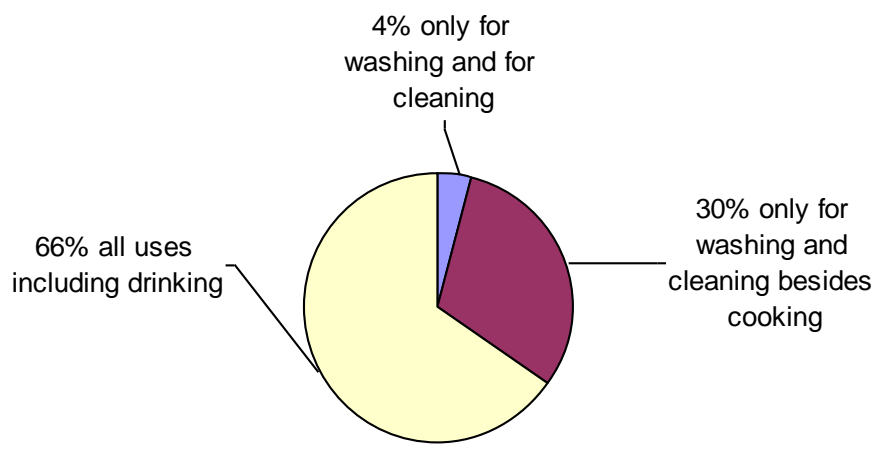

Fig. 3. Percentage of using harvested water for 30 families not having cisterns

It was found that $41.08 \%$ of the 60 surveyed families dislike the taste of harvested water, and said that it has a bitter taste and $8.93 \%$ of the families claim that well water has a smell. No specific water borne diseases were reported in the study village. 


\subsection{Water quality}

\subsubsection{Fresh water}

The results presented in Table 2 reveal that the fresh rainwater is acidic, with low TDS and conductivity values. But turbidity was relatively high because air during the research period was dusty. Ammonia concentration was also low and ortho-phosphate $\left(\mathrm{PO}_{4}^{-3}\right)$ was negligible, since the study location is far from the sea.

\subsubsection{Harvested rainwater stored in underground cisterns}

The quality results of harvested rainwater in underground cisterns are presented in Table 3 . The results show that most of the cisterns water is alkaline with $\mathrm{pH}$ values within the WHO recommended range (6.5-8.5) [18]. It is probably due to accumulation of alkaline sediments in the cistern, probably from the cistern walls. The harvested water is aerobic with DO values in the range of $7.53-8.42 \mathrm{mg} / \mathrm{L}$. The TDS concentration of the harvested rainwater is acceptable for drinking. The WHO recommends that the TDS shouldn't be more than 500 $\mathrm{mg} / \mathrm{L}$, and classify drinking water taste with TDS below $300 \mathrm{mg} / \mathrm{L}$ as excellent [18]. It was noticeable that the TDS of all tested samples increased during storage. The turbidity values are below 5 NTU recommended by the WHO and Palestine Standards Institution [18]. Turbidity increases during water extraction from the cistern due to the re-suspension of accumulated sediments at the bottom of the cisterns and from the un-cemented walls of the cisterns themselves [19]. According to [20], the most effective cleansing process for roof runoff is natural sedimentation in the storage tank. Therefore, the simplest method of treatment is to avoid turbulent mixing within the cistern to prevent the sediment from mixing within the water column. These sediments should be removal regularly. The construction and frequent cleaning of sediment trap basin at the head of the water inlet of the cistern help in treating the collected water to acceptable turbidity levels. An additional improvement could be reached by inclining the cistern floor by up to $5 \%$, which ends with a sediment trap basin at the end corner.

The orthophosphate concentrations in the tested samples were negligible. Similarly, the results revealed acceptable $\mathrm{SO}_{4}{ }^{-}$concentrations as compared with the WHO recommended value for drinking water of $400 \mathrm{mg} / \mathrm{L}$ and the Palestine Standards Institution of $200 \mathrm{mg} / \mathrm{L}$. No noticed change in the concentration of sulphate during storage. With respect to ammonium, all of the tested samples had lower values than that recommended by the WHO of $0.50 \mathrm{mg} / \mathrm{L}$, except cistern number 2 in the second sample. So it can be concluded that the harvested rainwater in Almazra'a has low ammonium concentration because it's not an agricultural area. In a similar previous study done in Galicia, NW Spain [21] reported that high values for $\mathrm{NH}_{4}{ }^{+}$in forestry and agricultural activities areas with an extensive use of fertilizers.

Table 2. Water quality tests results for two samples of fresh rainwater collected in Almazra'a Al Gharbiyya village/ Palestine

\begin{tabular}{||l|l|l|l||}
\hline Parameter tested & Units & Sample (1) & Sample (2) \\
\hline Temperature & ${ }^{\circ} \mathrm{C}$ & 15.9 & 16.4 \\
\hline $\mathrm{pH}$ & - & 6.91 & 6.13 \\
\hline Conductivity & $\mu \mathrm{s} / \mathrm{cm}$ & 17 & 18.6 \\
\hline TDS & $\mathrm{mg} / \mathrm{L}$ & 8 & 9 \\
\hline DO & $\mathrm{mg} / \mathrm{L}$ & 13.75 & 10.44 \\
\hline Turbidity & $\mathrm{NTU}$ & 9.8 & 15.9 \\
\hline $\mathrm{FC}^{\dagger}$ & $\mathrm{\#} / 100 \mathrm{~mL}$ & & \\
\hline
\end{tabular}




\begin{tabular}{||l|l|l|l||}
\hline Parameter tested & Units & Sample (1) & Sample (2) \\
\hline $\mathrm{PO}_{4}{ }^{-3}-\mathrm{P}$ & $\mathrm{mg} / \mathrm{L}$ & 0.023 & 0.001 \\
\hline $\mathrm{NH}_{4}{ }^{+}-\mathrm{N}$ & $\mathrm{mg} / \mathrm{L}$ & 1.61 & 1.73 \\
\hline $\mathrm{SO}_{4}{ }^{-2}$ & $\mathrm{mg} / \mathrm{L}$ & 4.06 & 5.43 \\
\hline
\end{tabular}

$\dagger \mathrm{FC}$ was measured in other samples and was found zero (Abdelhamid and Mahmoud, in preparation)

Table 3. The course of harvested water quality for four cisterns in Almazra'a Al Gharbiyya village/ Palestine assessed over a month time interval

\begin{tabular}{|c|c|c|c|c|c|}
\hline \multirow[b]{2}{*}{ Parameter tested } & \multirow[b]{2}{*}{ Units } & \multicolumn{2}{|c|}{ Cistern 1} & \multicolumn{2}{|c|}{ Cistern 2} \\
\hline & & Sample 1 & $\begin{array}{c}\text { Sample } 2 \\
\text { after a } \\
\text { month } \\
\text { period } \\
\end{array}$ & Sample 1 & $\begin{array}{c}\text { Sample } 2 \\
\text { after a } \\
\text { month } \\
\text { period }\end{array}$ \\
\hline Temperature & ${ }^{\circ} \mathrm{C}$ & 14.5 & 21 & 15 & 20.9 \\
\hline $\mathrm{pH}$ & - & 8.15 & 6.76 & 8.29 & 8.50 \\
\hline Conductivity & $\mu \mathrm{s} / \mathrm{cm}$ & 272 & 410 & 291 & 311 \\
\hline TDS & $\mathrm{mg} / \mathrm{L}$ & 129 & 194 & 137 & 149 \\
\hline DO & $\mathrm{mg} / \mathrm{L}$ & 7.88 & 8.42 & 7.55 & 7.97 \\
\hline Turbidity & NTU & 1.34 & 1 & 0.97 & 0 \\
\hline $\mathrm{FC}$ & $\# / 100 \mathrm{~mL}$ & 15 & 19 & 1 & 2 \\
\hline $\mathrm{BOD}_{5}$ & $\mathrm{mg} / \mathrm{L}$ & 10.2 & 12.5 & 6.0 & 6.1 \\
\hline Ortho-phosphate $\mathrm{PO}_{4}{ }^{-3-} \mathrm{P}$ & $\mathrm{mg} / \mathrm{L}$ & 0.021 & 0.055 & 0.085 & 0.024 \\
\hline Ammonia $\mathrm{NH}_{4}^{+}-\mathrm{N}$ & $\mathrm{mg} / \mathrm{L}$ & 0.218 & 1.07 & 0.103 & 0.127 \\
\hline Sulphate $\mathrm{SO}_{4}^{-2}$ & $\mathrm{mg} / \mathrm{L}$ & 3.51 & 6.48 & 1.98 & 3.93 \\
\hline \multirow[b]{2}{*}{ Parameter tested } & \multirow[b]{2}{*}{ Units } & \multicolumn{2}{|c|}{ Cistern 3} & \multicolumn{2}{|c|}{ Cistern 4} \\
\hline & & Sample 1 & $\begin{array}{c}\text { Sample } 2 \\
\text { after a } \\
\text { month } \\
\text { period }\end{array}$ & Sample 1 & $\begin{array}{c}\text { Sample } 2 \\
\text { after a } \\
\text { month } \\
\text { period }\end{array}$ \\
\hline Temperature & ${ }^{\circ} \mathrm{C}$ & 18.9 & 23.8 & 16 & 20 \\
\hline $\mathrm{pH}$ & - & 6.50 & 8.29 & 7.46 & 8.07 \\
\hline Conductivity & $\mu \mathrm{s} / \mathrm{cm}$ & 25 & 222 & 29 & 249 \\
\hline TDS & $\mathrm{mg} / \mathrm{L}$ & 12 & 102 & 14 & 120 \\
\hline DO & $\mathrm{mg} / \mathrm{L}$ & 8.38 & 7.8 & 8.28 & 7.53 \\
\hline Turbidity & NTU & 1 & 1 & 1 & 1 \\
\hline $\mathrm{FC}$ & $\# / 100 \mathrm{~mL}$ & 1 & 2 & 50 & 55 \\
\hline $\mathrm{BOD}_{5}$ & $\mathrm{mg} / \mathrm{L}$ & 14.4 & 5.8 & 11.9 & 4.7 \\
\hline Ortho-phosphate $\mathrm{PO}_{4}{ }^{-3-} \mathrm{P}$ & $\mathrm{mg} / \mathrm{L}$ & 0.016 & 0.012 & 0.077 & 0.071 \\
\hline Ammonia $\mathrm{NH}_{4}^{+}-\mathrm{N}$ & $\mathrm{mg} / \mathrm{L}$ & 0 & 0 & 0.007 & 0.007 \\
\hline Sulphate $\mathrm{SO}_{4}^{-2}$ & $\mathrm{mg} / \mathrm{L}$ & 1.64 & 2.18 & 2.29 & 2.4 \\
\hline
\end{tabular}

\subsubsection{Harvested rainwater contamination due to cesspits}

The results presented in Table 1, for the 30 families having cistern reveal that the average distance between the cistern and the cesspit is $16.68 \mathrm{~m}$, with a wide range from $2 \mathrm{~m}$ to 150 $\mathrm{m}$. The location of the cesspits close to the underground cisterns for some families is critical and thus considered the primary source of pollution for the harvested water. All the families do not raise pigeons on their houses roofs, so pollution from pigeons should be minimal. The positioning of the cesspit-cistern is not complying with Palestinian standards which requires that cistern to be located upstream of the possible local source of pollution with a minimum distance of $15 \mathrm{~m}$ [3]. Besides, only $39 \%$ of the cesspits are constructed of concrete from all sides, $50 \%$ of the families have unlined cesspits, and $11 \%$ concrete from one side only. At 
the same time, $57 \%$ of the families have never emptied the cesspits as sewage seeps into the soil, and $14 \%$ empty them every year or more, while $29 \%$ empty them in less than two months.

The World Health organization [18] and the Palestine Standards Institution impose that drinking water should be free of Faecal Coliform $(0 / 100 \mathrm{~mL})$ to be considered safe. But the results presented in Table 4 reveal the existence of $\mathrm{FC}$ in the range $1-55 / 100 \mathrm{~mL}$. FC was high in cistern 4 , probably because it is very close and at the same level of the cesspit which had never been emptied. The FC in cistern 1 was also high. This indicates that harvested water should be protected from pollution and harvested water should be disinfected by for instance chlorine. All the families don't use chlorination for disinfection, and this apparently worsens the situation. According to [20], chemical disinfection of harvested rainwater is not necessary since it results in the formation of carcinogenic chlorinated hydrocarbons when using chlorine. They recommended using a sieve of $0.5-1 \mathrm{~mm}$ openings before the discharge pump, to prevent residues of the plumbing from entering the pump and the installation.

Table 4. Cisterns location in relation to cesspits; cesspits emptying frequency and microbial quality harvested water for four houses in Almazra'a Al Gharbiyya village/ Palestine

\begin{tabular}{|c|c|c|c|c|c|}
\hline \multirow[b]{2}{*}{ Cistern } & \multirow[b]{2}{*}{$\begin{array}{l}\text { Distance } \\
\text { between the } \\
\text { cistern and } \\
\text { cesspit (m) }\end{array}$} & \multirow[b]{2}{*}{$\begin{array}{l}\text { Location of the } \\
\text { cesspit with } \\
\text { respect to the } \\
\text { cistern }\end{array}$} & \multirow[b]{2}{*}{$\begin{array}{l}\text { Frequency of } \\
\text { emptying the } \\
\text { cesspit }\end{array}$} & \multicolumn{2}{|c|}{ FC } \\
\hline & & & & Sample 1 & $\begin{array}{c}\text { Sample } 2 \\
\text { after a } \\
\text { month } \\
\text { period }\end{array}$ \\
\hline 1 & 10 & Down stream & Every 6 months & 15 & 19 \\
\hline 2 & $>15$ & Down stream & Not emptied & 1 & 2 \\
\hline 3 & $>15$ & Down stream & Not emptied & 1 & 2 \\
\hline 4 & 3 & Same level & Not emptied & 50 & 55 \\
\hline
\end{tabular}

\subsection{Water demand and harvesting}

The calculated average daily per capita water consumption rates presented in Table 5 are lower than $100 \mathrm{~L} / \mathrm{c} . \mathrm{d}$, usually recorded for communities with better water supply in Palestine (2012). This is due to water shortage and probably to low level of living standard. The water consumption pattern is high in summer and low in winter.

Table 5. Average daily per capita water consumption (L/c.d) from the water supply network for random 50 families in Almazra'a Al Gharbiyya village/ Palestine

\begin{tabular}{|c|c|c|c|c|c|}
\hline \hline Jan \& Feb & Mar \& Apr & May \& Jun & Jul \& Aug & Sep \& Oct & Nov \& Dec \\
\hline 40 & 61 & 76 & 68 & 63 & 62 \\
\hline
\end{tabular}

In Almazra'a village, water from the network is cut-off only during summer period for an average duration of 15 days per month. The hot months are June to September, so the annual days of water cut-off is 60 days. From the PWA records the average precipitate in the study area over the last 10 years is $500 \mathrm{~mm} /$ year. This concludes, assuming a runoff coefficient of 0.9 , that each family is capable of collecting $60.2 \mathrm{~m} 3$ annually since the average catchments roof surface area is $133.68 \mathrm{~m} 2$. The average water consumption for 50 random families in Almazra'a is about $200 \mathrm{~m} 3$ / year per family [22]. Accordingly, the harvested rainwater can cover about $30 \%$ of their water consumption during the year. In other words it covers the consumption of 110 days, which means they can cover their demand during the 60 days/ year of water cut-off. 


\subsection{Financial feasibility}

Since each family is capable of harvesting an average $60.2 \mathrm{~m}^{3}$ of rainwater annually, a cistern volume of $65 \mathrm{~m}^{3}$ should be adequate. It was calculated that the total construction cost of a rectangular shaped cistern is 4,610 US\$ and the pear shaped is 2,220 US\$ approximately.

The cost of water obtained from the water supply network is $1 \mathrm{US} \$ / \mathrm{m}^{3}$, as a mean value ignoring the tariff policy. The average water consumption in Almazra'a is about $242 \mathrm{~m}^{3} /$ year for families having underground cisterns and $183 \mathrm{~m}^{3} /$ year for families without underground cistern (Table 1). The families who have underground cisterns are capable of saving the cost of buying $60 \mathrm{~m}^{3}$ of water. On the other hand, the families who do not have underground cisterns are obliged to buy water from water distribution tankers with a high cost of 3.33US\$ $/ \mathrm{m}^{3}$. In order to be able to cover their water need during the days of cut-off, they have to procure a minimum volume of $30 \mathrm{~m}^{3}$ with that price. The calculated present worth of the annual expenses of water consumption for three cases of a single family either having a rectangular shaped cistern, pear shaped cistern or haven't a cistern are summarized in Table 6.

Table 6. Present worth of the annual expenses of water consumption for three cases of a single family in Almazra'a Al Gharbiyya village/ Palestine either having a rectangular shaped cistern, pear shaped cistern or haven't cistern

\begin{tabular}{|c|c|c|c|}
\hline & $\begin{array}{c}\text { Rectangular } \\
\text { shaped cistern }\end{array}$ & $\begin{array}{c}\text { Pear shaped } \\
\text { cistern }\end{array}$ & $\begin{array}{c}\text { Without } \\
\text { cistern }\end{array}$ \\
\hline Capital cost of construction (US\$) & 4,610 & 2,220 & - \\
\hline $\begin{array}{c}\text { Present worth of annual expenses for water } \\
\text { consumption (US\$) }\end{array}$ & 5,714 & 5,714 & 8,350 \\
\hline Total cost (US\$) & 10,324 & 7,936 & 8,350 \\
\hline
\end{tabular}

+ Calculations are based on eq. 1

From a financial point of view, rainwater roof catchments system is feasible, for the case of constructing a pear shaped cistern, but not for the case of rectangular shaped cistern. Nevertheless, regardless of the economic feasibility of the harvesting system, people believe that rainwater harvesting is a typical and convenient solution that provides them easily with reliable quantities of water during cut-off days, and thus gives people a secure feeling. Not all houses have an underground cistern, that's due to the high initial capital cost.

\section{Conclusions}

Harvested rainwater was found to be a reliable source of water during days of water interruption, where the total water consumption during this period can be covered. Socially the system is acceptable but a lack of awareness in hygiene and in locating and constructing the cesspits was noticed in the study village. On monetary basis, the system is feasible for pear shaped cisterns, but the system has the economic added value of being convenient. In the past, cisterns were constructed and excavated manually, but nowadays people don't construct their own cistern manually and thus construction is limited due to financial constraints of constructing rectangular shaped cisterns. Subsidizing the system through governmental and/or non-governmental funds is highly recommended.

\section{Acknowledgements}

The technical support provided by the laboratories of Birzeit University is highly appreciated. Unfortunately, Mira Boullata, the co-author of this manuscript, passed away. 


\section{References}

1. Applied Research Institute - Jerusalem (ARIJ), Environmental Data Base, Report (2012)

2. Palestinian Water Authority (PWA) General Technical Specifications for the Construction of Harvesting Cisterns (Pear-shaped and rectangular) (2003)

3. Palestinian Water Authority (PWA), Water supply report 2010 (2012)

4. V. Mushchanov, V. Sievka, A. Veshnevska and D. Nemova, Procedia Engineer., 117(1) 1018-1026 (2015)

5. N. Vatin, M. Petrichenko, D. Nemova, A. Staritcyna and D. Tarasova, Appl. Mech. Mater., 633-634 1023-1028 (2014)

6. M. Petrichenko, N. Vatin, D. Nemova, N. Kharkov and A. Staritcyna, Appl. Mech. Mater., 627 297-303 (2014)

7. R. Davydov, V. Antonov, D. Molodtsov and A. Trebukin, Adv. Intell. Syst., 692, 915920 (2018)

8. V. Maslak, N. Nasonkina, V. Sakhnoskaya, S. Antonenko and D. Nemova, Procedia Engineer., 117(1), 985-994 (2015)

9. Palestinian central Bureau of Statistics, PCBS Estimated population count in mid-year for Ramallah and A-Bireh 2004-2010 (In Arabic) (2004)

10. N. Myazin, S. Logunov, V. Davydov, V. Rud', N. Grebenikova and V. Yushkova, J. of Phys.: Conf. Series, 929(1), 012064 (2017)

11. V. Davydov, V. Dudkin, N. Myazin and V. Rud', Instrum. Exp. Tech+., 61(1), 140-147 (2018)

12. N. Myazin, V. Davydov, V. Yushkova, T. Davydova and V. Rud', J. of Phys.: Conf. Series, 917(4) 042017 (2017)

13. V. Davydov, N. Myazin and T. Davydova, Russ. J. Nondestruct+., 53(7), 520-529 (2017)

14. American Public Health Association, Washington/ American Water Works Association/ Water Environment Federation, Standard Methods for the Examination of Water and Wastewater, 21st edn (2005)

15. V. Davydov, V. Dudkin and N. Myazin, J. Commun. Technol. El+., 61(10), 1159-1165 (2016)

16. M. Marusina, B. Bazarov, P. Galaidin, M. Marusin, A. Silaev, E. Zakemovskya and Y. Mustaev, Meas. Tech+., 57(5) 580-586 (2014)

17. Yu. Neronov and N. Seregin, Meas. Tech+., 55(11), 1287-1293 (2013)

18. World Health Organization (WHO), Guidelines for drinking-water quality. 3rd ed. Incorporating the first and second agenda, 1, (2008)

19. W. Awadallah, Technical paper, Palestinian Hydrology Group (PHG) (2004)

20. T. Herrmann and U. Schmida, Urban Water, 1, 307-316 (1999)

21. A. Vázquez, M. Costoya, R. Peňa, S. García and C. Herrero, Chemosphere, 51, 375-386 (2003)

22. JWU (2017) Water supply record, Jerusalem Water Undertaking Company 